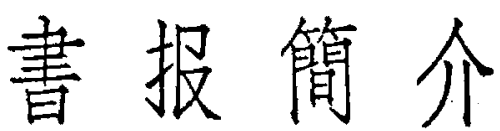

科学出版社 1957 年創刊的 18 种科学期刊

1957 年，科学出版社將出版科学期刊 90 种，其 中有 18 种是新㔊刊的或复刊的。在新創刊的期刊中， 有中国科学院力学研究所程的“力学学报” (季们)、 中国电子学会主稚的“电子学学报” (牛年刊)、中国农 莱机械学会主編的“农業机械学报”（牛年刊）、中国科 学院古奉椎动物研究室絧唖的“古春椎动物与古人类”

（季刊）等。此外，中国生理学会为了介紹国內外生 理科学最新的研究成就，还将創刊綜合性的学术刊物 “生理科学的进屡”(季F门)。

在中短性的科学期刊方面, 邻刊的有: 中国科学 院数学物理学化学部高分子化学研究 委 員会 絧湿的 “高分子通訊”（季叮）、中国敏洋湖沼学会綪輯的“海 洋湖沼学通訊”（不定期）、中国动物学会主繶的"中国 动物学杂志”（季刊）、中国植物病理学会主洞的“植病

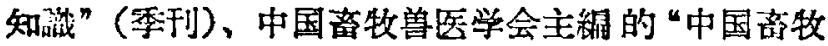
学杂志”（双月刊）、中国兽医学杂志”（双月刊）等。

在科学情报方面，中国科学院科学情报研究所去 年絋譯了“科技快报”（不定期），“科学新聞”（4月 刊)、“机械制造交摘”（牛月刊）等 3 种刊物; 合年还 將粨罣“力学交摘” (月刊)、“物理文摘”（月刊）、“冶 金文摘”(月刊)、“化学学俞文索引”(月刊)等 4 种刊物。

此外，今年复刊的猢刊則有中国科学院程摆出版 委員会編輯的“科学紀录”（双月刊）、中国化学工程 学会主程的“化工学报”(季刊)和中国地質学会程陆的 “地質論詐”（季扪)等。

\section{〔武 高〕}

\section{“原子能”}

由中国物理学会“原子能”絋譯委員会糖輯、科学 出版酎出版的学术性期扪“原子能”，已于 1956 年 10 月創刊。該刊的主要內容, 是刊登国內外有关原子核 物理、原子动力工程、原子能資源、放射性同位素的 应用、原子能保安技术等方面的文章。

“原子能”前 6 期將全部刊載苏联“原子能”杂志的 文密，以后將逐步刊載我国和其他国家的有关此方面 的畒作。

在绿近出版的一管一期中，計刊登有反应堆、純

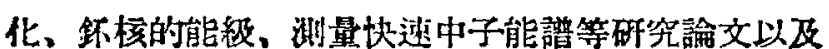

【武高〕

\section{“地質学报”展开大地構造的討論}

最近一期的“地筫学报”（36 3 期)，以几占满

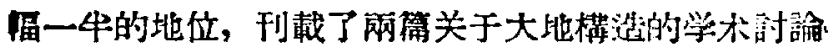
交章。第一篇是陈国达的“抌国地台“活化区”的实例 抹著重討論 “华夏古陆”問題”。該文作者以陽山和东 南沿海地区为实例，广泛地收集了有关該地区的地经，

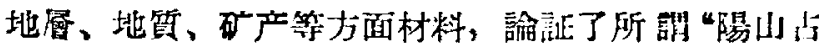
陆”和“华夏古陆”，是“活化”的地台区。作省不间，

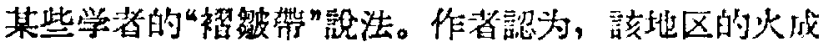

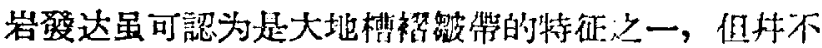
是唯一的特征; 只有詳細地研究和洘虑到䠹地区的圶 部構溜筑展史和整个特点，手能决定一个地区的入地

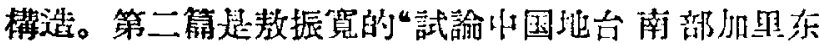

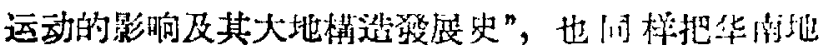

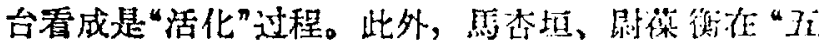

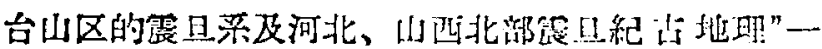

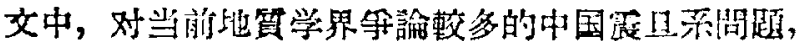
提出了不同論点。

\section{〔武高〕}

\section{“生活条件与健康”}

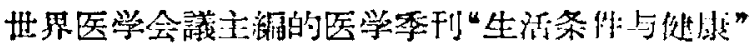

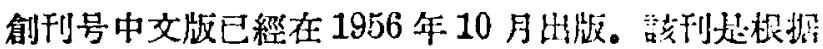
1953年在維世納举行的头于研究現代生活条作的世罗

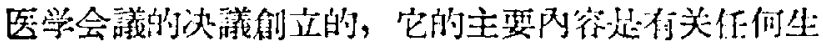
活条件足以显明地影响健畓的各个方面的研究战来和 工作䋑驗。

“生活条件与侹康”以同一队容和北京、莫斯科、 倫敦、巴黎、聖地亞哥、維地䋱等地分别出收。

这一刊物的学术委員会包括20个国家的35垃匠学

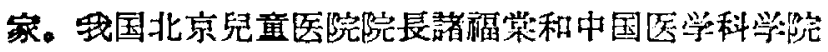
院曼沛其霞鄀是这个国际性医学李们的学术娄叮。

\section{“世界交化史遍报”}

苏联科学院从今年起將出版“所界文化史近报” (Востник истории мировой культуры) 双月刊，整門探 討从古代到現代的物質交化和精种交化的历j史间题。 除將表苏联与其他国家学者的有关部会恐想、科兴、 枝术及艺术的历史問題的研究論文外，还將留进行名 国学者所关心的文化史問题的討論，阔时將登 载部

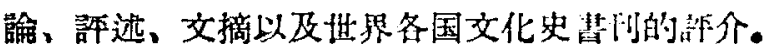

